\title{
Does Income Smoothing Make Stock Prices More Informative?
}

June, 2002

\author{
Paul Zarowin \\ New York University \\ Stern School of Business \\ $\mathrm{Ph}:$ 212-998-0015 \\ Fax: 212-995-4004 \\ e-mail: pzarowin@stern.nyu.edu
}

I thank participants at the NYU-Columbia accounting seminar and at the London Business

School accounting seminar for their helpful comments. Financial support of the Ross Institute for Accounting Research is gratefully acknowledged. 


\begin{abstract}
This paper presents a new approach to studying the effects of earnings management, by testing whether income smoothing, a particular form of earnings management, is associated with more informative stock prices. Stock price informativeness is defined as the amount of information about future earnings and cash flows reflected in current period stock returns, and is measured as the coefficient on future earnings (cash flows) in a regression of current stock return against current and future earnings (cash flows and accruals). I find that firms with greater smoothing have more informative stock prices, implying that managers use income smoothing to reveal their private information about the firm's future profitability.
\end{abstract}




\section{Introduction}

In this paper, I seek to answer the question: "Does income smoothing make stock prices more informative?", where stock price informativeness is defined as the amount of information about future earnings and cash flows that is reflected in current period stock returns. This is an important question to answer, because the effects of earnings management in general, and of income smoothing in particular, on stock price efficiency and resource allocation, are largely unknown. If income smoothing causes more (less) information to be impounded into stock prices, it likely improves (aggravates) resource allocation. ${ }^{1}$ As Healy and Wahlen (2000) discuss in their review of the earnings management literature, the extent to which management's financial reporting discretion is used to improve communication vs misused to manage earnings, and the extent to which market participants see through vs fail to detect earnings management, are open questions. No other study examines the consequences of earnings management in terms of its affects on the amount of information about future earnings and cash flows reflected in current stock returns. Thus, this paper presents a new approach to studying the effects of earnings management.

Income smoothing is defined as the management of accruals (net income - CFO) to offset variation in $\mathrm{CFO}$, such that the time-series variation in income is reduced, given the variation in CFO (which is assumed to be exogenous). I measure income smoothing as (1) the variation of net income relative to the variation in $\mathrm{CFO}$, or (2) the correlation between changes in accruals and changes in CFO. Ceteris paribus, more income smoothing is evidenced by a lower relative variation in net income and a lower (or negative) correlation between accruals and CFO.

\footnotetext{
${ }^{1}$ Tobin (1982) refers to this as functional efficiency. Durnev, et. al. (2001) discuss the link between informational efficiency and functional efficiency.
} 
Because discretionary smoothing behavior is unobservable, any test of earnings management is a joint test of both the hypothesis in question and the measure of earnings management. This caveat is pertinent here, because the smoothing measures might be capturing non-discretionary (inherent) smoothing. To address this issue, I decompose total accruals into estimates of their managed vs unmanaged components, using the cross-sectional version of the Jones (1991) model), and I construct smoothing measures based on managed accruals also.

Stock price informativeness is defined as the amount of information about future earnings or future cash flows that is reflected in the current period stock return. I measure informativeness as the coefficient on future earnings (cash flows) in a regression of current stock return against current and future earnings (cash flows and accruals). I refer to these measures as the future earnings response coefficient, FERC, and the future cash flow response coefficient, FCFRC. Ceteris paribus, firms whose stock returns reflect more information about future earnings and cash flows have higher stock price informativeness, and thus higher FERC and FCFRC. ${ }^{2}$

The relation between income smoothing and stock price informativeness is important for both academics and policymakers, because it relates to the perennial question of how much accounting discretion (i.e., ability to manage earnings) should firms have? As Schipper (1989) points out, "research results have not shed any light on the issue of whether some change in the amount of managerial discretion might even add to the informativeness of accounting earnings".

The accounting literature hypothesizes two opposite effects of income smoothing on stock price informativeness. One viewpoint is that income smoothing obfuscates information and thus makes stock prices less informative (efficient). In this view, income smoothing results in

\footnotetext{
${ }^{2}$ As discussed below, it is important to use future cash flows as well as future earnings as the regressor, because the coefficient on future earnings might be higher for firms with more smoothing, since smoother earnings are less variable and more predictable.
} 
less information about future earnings and cash flows reflected in current stock prices, implying that discretion is detrimental. This view is often associated with former SEC chairman Arthur Levitt (1998), who chastised firms for their use of "cookie jar" reserves to manage earnings. The alternative viewpoint is that managers use income smoothing to reveal their private information about the firm's future profitability (Ronen and Sadan [1981], Chaney and Lewis [1995], and Kirschenheiter and Melumad [2002]). In this case, income smoothing results in more information about future earnings and cash flows reflected in current stock prices, implying that discretion is beneficial. ${ }^{3}$ Thus, the two opposing viewpoints make diametrically opposite predictions, and the relation between income smoothing and stock price informativeness is ultimately an empirical question. If income smoothing makes stock prices more (less) informative, firms experiencing more smoothing should have higher (lower) FERC and FCFRC, ceteris paribus. Almost certainly, both obfuscating and informative earnings management occur. In this paper, I test which prediction is more accurate on average.

I regress current returns against current and future earnings and against current and future cash flows and accruals for firms with high vs low measures of income smoothing, and I compare the coefficients on the future earnings and cash flows. I find that firms with greater income smoothing have higher FERC and FCFRC. This result is robust to various robustness checks, such as the inclusion of control variables and alternative constructions of the smoothing measures. This is the first empirical evidence that a particular form of earnings management, income smoothing, is associated with more informative stock prices.

The rest of the paper is organized as follows. Section 2 reviews prior earnings management research. Sections 3 and 4 discuss my measures of income smoothing and stock

\footnotetext{
${ }^{3}$ For example, Hand (1989) suggests that a smoothing action, recognizing a gain from a debt-equity swap, is used by management to convey the information that the pre-smoothed earnings decrease is transitory.
} 
price informativeness. Sections 5 and 6 discuss the test methodology and report the results of the primary empirical tests. Section 7 reports the results of robustness tests. Section 8 reports the results of tests based on the Jones (1991) model. Section 9 concludes.

\section{Relation to Prior Research}

My research contrasts with most prior studies on earnings management, which have focused on detecting whether and when earnings management takes place, and if it does, is the stock market fooled by it. Studies have used either general measures of earnings management based on total accruals, or specific measures of earnings management based on particular accruals, such as bank loan loss provisions or deferred tax valuation allowances. These tests typically involve estimating a regression model (such as the Jones (1991) model or a variant) to decompose accruals into fitted and residual components, which represent "normal" and managed accruals. Researchers then examine the behavior of residual accruals in certain contexts to test whether earnings management has occurred. Significantly positive or negative abnormal accruals is evidence of earnings management.

If earnings management is found, the next question is whether the market efficiently sees through the manipulation. To test this, long or short positions are taken in the sample firms (which direction depends on the context), and abnormal stock returns subsequent to the event are examined. For example, Teoh, Welch, and Wong (1998) and Teoh, Wong, and Rao (1998) test the hypothesis that firms inflate earnings when they want to sell stock. DeAngelo, DeAngelo, and Skinner (1994), and DeFond and Jiambalvo (1994) examine whether firms inflate earnings to avoid violating debt covenants. These studies test whether managed accruals are positive when 
firms issue securities or face potential covenant violations, and whether these events are followed by negative abnormal returns. ${ }^{4}$

My tests are different in a number of ways. Since I do not decompose total accruals into its fitted and residual components, my tests are not vulnerable to potential mis-measurement of abnormal accruals. This is important, because recent studies (Guay, Kothari, and Watts [1996] and Kothari, Leone, and Wasley [2001]) have challenged the efficacy of extant accruals models. Since I do not decompose accruals into their normal vs managed components, my tests are subject to a related measurement error problem: I might be attributing accrual variation to the managed component, whereas it is really due to intrinsic variation. Of course, since normal and managed accruals are unobservable to the researcher, there is no good way around this problem. I deal with this issue by ranking firms by my smoothing measures by industry (and year), under the assumption that industry and year are good proxies for inherent accrual variation. Under this assumption, my ranking sorts by discretionary accruals. To test the robustness of my results, however, I perform additional tests where I use the Jones model to decompose total accruals, and I construct smoothing measures based on the managed component.

More importantly, since I examine relative informativeness, my tests do not imply, require, or test that stock prices are (semi-strong form) efficient. While informativeness is intimately related to efficiency, my approach to addressing the informativeness/efficiency question has a number of advantages over the conventional approach of calculating abnormal returns. First, because of the Fama (1970) joint test problem, we can never be sure whether we are really finding excess returns or mis-measured risk.

\footnotetext{
${ }^{4}$ See Healy and Wahlen (2000) for a comprehensive list of studies. Some studies, such Burghstaler and Dichev (1997) and DeGeorge, Patel, and Zeckhahser (1999) examine the distribution of earnings to infer whether earnings management has occurred, without examining accruals.
} 
Perhaps most important, when evaluating the effects of income smoothing (and in many other cases) it is not clear over what period to calculate excess returns, or in which firms to take long vs. short positions. Previous studies generally take short (long) positions in firms with positive (negative) abnormal accruals, to test whether the earnings management has fooled the market into over (under) valuing such firms. When the earnings management measure is a nondirectional statistic like a standard deviation or correlation, it is not obvious which firms to go long or short in (i.e., which firms are under- or over-valued), which is necessary to calculate portfolio abnormal returns. The informativeness methodology avoids this issue by examining how much current returns reflect future information, rather than whether future returns can be earned based on current information.

The closest papers to mine are Subramanyam (1996) and Hunt, Moyer, and Shevlin (HMS, 2000). Subramanyam finds evidence of income smoothing in the negative correlations between accruals and CFO and between discretionary and non-discretionary accruals (from the Jones model). He also finds that discretionary accruals predict future profitability, which is consistent with managers using income smoothing to convey private information. HMS construct a measure of discretionary income smoothing based on the Jones model, and they show that discretionary smoothing enhances informativeness, defined by the contemporaneous priceearnings relation. However, the contemporaneous relation cannot address the issue of whether smoothing makes prices more or less efficient by revealing or obfuscating information about the firm's future prospects. Hunt, Moyer, and Shevlin also conduct some earnings forecasting tests, but like Subramanyam, price or return is not one of their forecasting variables, so they cannot address the issue of how much information is reflected in prices. Thus, no other papers examine 
earnings management by focusing on the relation between current prices and future information (earnings or cash flows). ${ }^{5}$

\section{Measures of Income Smoothing}

Income smoothing is defined as the management of accruals to offset variation in CFO, such that the time-series variation in income is reduced, given the variation in $\mathrm{CFO} .{ }^{6} \mathrm{I}$ use two measures of income smoothing. The first is $\rho(\Delta \mathrm{ACC}, \Delta \mathrm{CFO})$, the correlation between changes in accruals and changes in CFO, which has been used by both Myers and Skinner (1999) for quarterly data and by Leuz, Nanda, and Wysocki (2001) for annual data. The second is $\sigma_{\mathrm{NI}} / \sigma_{\mathrm{CFO}}$, the variation of net income relative to the variation in $\mathrm{CFO}$, which has been used for annual data by Leuz, Nanda, and Wysocki and by Bhattacharya, Daouk, and Welker (2001). A greater degree of income smoothing is evidenced by a lower relative variation in net income and a lower (or more negative) correlation between accruals and CFO. As in any study of earnings management, my tests are joint tests of both the specific hypothesis (whether smoothing makes prices more or less informative) and the measures of earnings management.

Both measures are intuitively appealing, because they capture the concept that income is smoothed by variation in accruals offsetting variation in CFO, thus lowering the variation in income for a given amount of variation in CFO. Additionally, Myers and Skinner "validate" their measure by showing that firms which are hypothesized to engage in income smoothing (those attempting to sustain a series of consecutive increases in quarterly EPS) have more negative correlations between changes in accruals and changes in CFO.

\footnotetext{
${ }^{5}$ Defond and Park (1997) also find evidence of discretionary smoothing by examining the relation between current earnings, analysts forecasts of future earnings, and discretionary accruals.

${ }^{6}$ Ronen and Sadan (1981) refer to this type of smoothing as "intertemporal smoothing".
} 
To construct my measures, I use annual data, based on the assumption that management attempts to smooth year-to-year variations in income. For NI and CFO I use Compustat \#18 (net income before extraordinary items and discontinued operations) and \#308, respectively; accruals $=\mathrm{NI}-\mathrm{CFO}$. I use three years of NI and CFO to construct $\sigma_{\mathrm{NI}} / \sigma_{\mathrm{CFO}}$, and three years of changes in accruals and changes in $\mathrm{CFO}$ to construct $\rho(\Delta \mathrm{ACC}, \Delta \mathrm{CFO})$. The smoothing measures are calculated using the three years including the current year but not the future year, so there is no necessary relation between a smoothing measure and the predicted variable, future earnings or cash flows. This is important, because smoother earnings are more persistent and forecastable, and have a higher FERC. Thus, if future earnings were included in the smoothing measures, we might induce a relation between smoothing and the FERC. The smoothing measures include the current year, because a firm's smoothing behavior (i.e., observed cash flows, accruals, and earnings) thru the end of year $t$ is part of the information in $\mathrm{P}_{t}$ and thus in $\mathrm{R}_{\mathrm{t}}{ }^{7}$

Thus, for example, to explain stock returns for 1995 using earnings or cash flows for 1995 and 1996 as explanatory variables, $\sigma_{\mathrm{NI}} / \sigma_{\mathrm{CFO}}$ uses NI and CFO for 1993, 1994, and 1995, while $\rho(\Delta$ ACC, $\Delta$ CFO) uses ACC and CFO for 1992, 1993, 1994, and 1995 to construct changes for 1993, 1994, and 1995. Each year's NI, CFO, and ACC figure is deflated by total assets at the beginning of the year. Three observations is a minimum necessary to compute meaningful measures, while using more than three would involve using stale data. Since Compustat CFO data begin in 1987 and end in 2000, the number of annual observations is already limited and would be further reduced if a longer series were used to construct the smoothing measures. Since

\footnotetext{
${ }^{7}$ Although the smoothing measures are constructed using only data that is observable to the market, the implicit assumption is that management sets the accruals using private information.
} 
the Compustat CFO data begin 1987 and I need four lags to compute $\rho(\Delta \mathrm{ACC}, \Delta \mathrm{CFO})$, the first effective year is 1991 .

An alternative approach is to calculate the smoothing measures for each firm using the full time-series of data, so that each firm has one smoothing statistic. I do not follow this method for a number of reasons. First, I would lose many firms that do not have the full time-series of data. Second, a firm's smoothing behavior may change over time, and one constant statistic would not capture this. Finally, the smoothing measure would coincide with the future earnings and cash flow period, creating a potential simultaneity problem.

Many earnings management papers use the "balance sheet" approach to compute accruals, and then derive CFO as NI - accruals. While the balance sheet method allows a longer time series, I do not use this method, because Collins and Hribar (2001) show that it often mismeasures accruals and CFO.

Table 1 shows sample statistics for the variables used in this study, pooled over all firmyears. As expected and consistent with Myers and Skinner, I find that (changes in) accruals and cash flows are strongly negatively correlated for most firms, with a median correlation of -.926. This results in net income being less variable than CFO, with a median $\sigma_{\mathrm{NI}} / \sigma_{\mathrm{CFO}}$ ratio of $.816^{8}$

Table 2 shows that both measures are highly correlated with each other, as expected, since a higher correlation between accruals and cash flows causes the variance of net income to be high relative to the variance of cash flows. Also not surprisingly, the rank correlation between the two smoothing measures (.471) is higher than their Pearson correlation (.220), due to the presence of outliers that affect the latter but not the former.

\footnotetext{
${ }^{8}$ The mean $\sigma_{\mathrm{NI}} / \sigma_{\mathrm{CFO}}$ greater than one is due to outliers. As discussed below, the ranks of the smoothing measures, and not the raw measures, are used in my regressions. Thus, there is no need to remove outliers.
} 


\section{Measures of Stock Price Informativeness}

My stock price informativeness measures (how much information about future earnings or cash flows is capitalized into price) are based on Collins, Kothari, Shanken, and Sloan (1994), and have been used to measure price informativeness by Gelb and Zarowin (2002), Lundholm and Myers (2002), and Durnev, Morck, Yeung, and Zarowin (2001). ${ }^{9}$ Collins et. al. assume revisions in expected dividends to be correlated with revisions in expected earnings. This allows them to express current stock returns as a function of the current period's unexpected earnings and changes in expected future earnings.

A key problem in estimating this relationship is that unexpected earnings and changes in expected future earnings are unobservable. I follow Collins et. al. (1994) and proxy for current unexpected earnings using current change in earnings, and for changes in expected future earnings using changes in reported future earnings. This results in a regression of current annual stock returns, $\mathrm{R}_{\mathrm{t}}$ on lagged, current, and future annual earnings (firm subscripts omitted): ${ }^{10}$

$$
R_{t}=a+b_{0} E_{t-1}+b_{1} E_{t}+b_{2} E_{t+1}+b_{3} R_{t+1}+u_{t}
$$

where the earnings variables are in per share form and are scaled by the share price at the beginning of the current year. ${ }^{11}$ The stock returns in (1), $\mathrm{R}_{\mathrm{t}}$, are total annual stock returns, defined as capital gain plus dividend yield, and are calculated from data reported in COMPUSTAT. $b_{1}$ is the earnings response coefficient, ERC, and $b_{2}$ is the future earnings response coefficient, FERC. Both $b_{1}$ and $b_{2}$ are hypothesized to be positive, with $b_{1}>b_{2}$, since

\footnotetext{
${ }^{9}$ Other recent papers that have used the informativeness measure are Ayres and Freeman (2001), Jiambalvo, Rajgopal, and Venkatachalam (2001), and Piotroski and Roulstone (2002).

${ }^{10}$ Lundholm and Myers (2002) derive a regression of returns on future earnings based on the residual income valuation model (Ohlson [1995]). Note that the levels model (1) is econometrically equivalent to the regression with current and future earnings change as explanatory variables: $R_{t}=a+\beta_{0}\left(E_{t}-E_{t-1}\right)+\beta_{1}\left(E_{t+1}-E_{t}\right)+u_{t}$ where $\beta_{0}=-b_{0}$, $\beta_{0}-\beta_{1}=b_{1}$, and $\beta_{1}=b_{2}$.

${ }^{11}$ If the deflator is beginning-of-period earnings, the independent variable is undefined when the denominator is negative or zero. To avoid having to delete firms with negative or zero earnings, I scale by beginning of year price $\mathrm{P}_{\mathrm{t}-1}$.
} 
current returns are affected more by observable current earnings than by (as yet) unobservable future earnings. $b_{0}$ is hypothesized to be negative. If the market views earnings as a random walk, then $b_{0}=-b_{1}$. Rather than impose this condition, I allow the regression to determine the coefficients, because the market might not view earnings as a random walk. The more mean reverting earnings are, the smaller (in absolute value) is $b_{0}$ relative to $b_{1}{ }^{12}$

Because their goal is to maximize the $\mathrm{R}^{2}$ of the returns-earnings model, Collins et al. include three future years of earnings and returns in their regression. My goal is to test whether the future response coefficient varies with the degree of income smoothing. Since my goal is not to maximize $\mathrm{R}^{2}$, and since including more future years effectively reduces the sample size, I include only one future year in my regression. Furthermore, since longer horizon earnings are harder to forecast, if there is a difference in the future response coefficient related to income smoothing, it is most likely to be detectable for the nearest year, $t+1$, rather than for a more distant future period. Since the Compustat data end in 2000, the latest years for $R_{t}$ and $R_{t+1}$ are 1999 and 2000. Thus, my sample runs from 1991-1999.

Collins et al. (1994) argue that using the actual future earnings introduces an error in variables problem in (1), since the theoretically correct regressor is the unobservable expected future earnings. This measurement error problem biases downward estimates of the future earnings coefficients. To correct for this bias, I follow them and include the future return as a control variable. The hypothesized coefficient on $\mathrm{R}_{\mathrm{t}+1}$ is negative.

By definition, income smoothing reduces the variation of net income. Less variable earnings are more predictable, and thus should have a higher FERC, by construction. Thus, if future earnings is used as a regressor in (1), it might be tautological to find that the FERC varies

\footnotetext{
${ }^{12}$ This can be seen by rewriting (1) with $b_{1}\left(E_{t}-\gamma E_{t-1}\right)$ where $\gamma=-b_{0} / b_{1}$.
} 
negatively with my measures of income smoothing. To deal with this issue, I decompose net income into cash flows from operations and accruals, thereby letting the coefficients on the two components of net income differ, and I also estimate the regression:

$$
\mathrm{R}_{\mathrm{t}}=\mathrm{a}+\mathrm{b}_{0} \mathrm{CF}_{\mathrm{t}-1}+\mathrm{b}_{1} \mathrm{CF}_{\mathrm{t}}+\mathrm{b}_{2} \mathrm{CF}_{\mathrm{t}+1}+\mathrm{c}_{0} \mathrm{ACC}_{\mathrm{t}-1}+\mathrm{c}_{1} \mathrm{ACC}_{\mathrm{t}}+\mathrm{c}_{2} \mathrm{ACC}_{\mathrm{t}+1}+\mathrm{b}_{3} \mathrm{R}_{\mathrm{t}+1}+\mathrm{u}_{\mathrm{t}}
$$

In (2), the primary coefficient of interest is $b_{2}$, the future cash flow response coefficient, FCFRC. Since income smoothing, by definition, involves the manipulation of accruals, it should affect the FERC thru $c_{2}$, the coefficient of $\mathrm{ACC}_{\mathrm{t}+1}$, not thru $\mathrm{b}_{2}$, the coefficient of $\mathrm{CF}_{\mathrm{t}+1}$. Thus, the coefficient of $\mathrm{CF}_{\mathrm{t}+1}$ can be interpreted as an informativeness measure. Given adequate controls, higher values of $b_{2}$ indicate that current returns capitalize more information about future cash flows.

The expected coefficients in (2) are analogous to those in (1). The coefficients on current and future cash flows and accruals, $b_{1}, b_{2}, c_{1}$, and $c_{2}$ are hypothesized to be positive, with $b_{1}>b_{2}$ and $c_{1}>c_{2}$. The coefficients on lagged cash flows and accruals, $b_{0}$ and $c_{0}$, are hypothesized to be negative. The relative magnitudes of $b_{0} v s b_{1}$ and of $c_{0} v s c_{1}$ depend on how mean reverting the market views cash flows and accruals. Based on previous studies on the pricing of current cash flows and accruals (e.g., Rayburn [1989], Bowen, Burghstaler, and Daley [1989], and Livnat and Zarowin [1990]), I expect $b_{1} \approx c_{1}$. Since accruals are probably more predictable than cash flows, I expect $b_{2}<c_{2}$.

Table 1 shows pooled sample statistics for the variables used in the regressions. I delete outliers defined as bottom and top $1 \%$ of lagged, current, and future (scaled) earnings, cash flows, and accruals, and current and future stock return, based on each year's distribution. Even with outlier deletion, there are still some extreme values of these variables. Table 1 shows that 
both earnings and accruals are strongly left-skewed. This is not surprising, since accounting is conservative, and losses tend to be recognized immediately, while gains are deferred.

Table 2 shows correlations between the regression variables. Pearson (Spearman rank) correlations are above (below) the diagonal. Returns are positively correlated with (scaled) earnings, cash flows, and accruals. Since accruals naturally smooth cash flows (even without intentional income smoothing), returns are more highly correlated with earnings than with either of its components, as expected. Also as expected, accruals and cash flows are strongly negatively correlated, due to the combination of natural and intentional smoothing. Additionally, the data reveal the familiar book-to-market effect $(\mathrm{B} / \mathrm{M})$, with high $\mathrm{B} / \mathrm{M}$ firms having higher returns than low B/M firms.

The Spearman correlations in Table 2 show that earnings and returns are negatively correlated with the smoothing measures. Recall that a higher smoothing statistic means less smoothing. Thus, a negative correlation means that more successful firms smooth more. This is consistent with signaling views of smoothing, wherein more successful firms are most able to smooth. ${ }^{13}$

\section{Empirical Framework}

My empirical objective is to examine the relation between stock price informativeness as measured by the future earnings response coefficient, FERC, and the future cash flow response coefficient, FCFRC, and measures of income smoothing. As pointed out above, since we are unable to observe the managed component of accruals, the smoothing measures are confounded by intrinsic accrual variation due to real business and accounting factors. To control for this

\footnotetext{
${ }^{13}$ Also consistent with this view, the Spearman correlations between the smoothing measures and future returns and earnings are negative.
} 
variation, I rank firms by each smoothing measure each year within each ( 2 digit SIC code) industry, as long as the industry-year has a minimum of 30 observations. I then convert the industry-year ranks to percentiles: (rank-1)/(number of firms in industry-year -1). This yields percentile rankings for each industry-year ranging from zero (for the lowest ranking firm) to one (for the highest ranking firm). If industry and time are good proxies for inherent accrual variation, this method produces the desired ranking by managed accruals. I interact these percentiles with the independent variables in (1) and (2), and I estimate the regressions: ${ }^{14}$ $R_{t}=a+b_{0} E_{t-1}+b_{1} E_{t}+b_{2} E_{t+1}+b_{3} R_{t+1}+\alpha D_{t}+\beta_{0} D_{t} E_{t-1}+\beta_{1} D_{t} E_{t}+\beta_{2} D_{t} E_{t+1}+\beta_{3} D_{t} R_{t+1}+u_{t}$

and

$\mathrm{R}_{\mathrm{t}}=\mathrm{a}+\mathrm{b}_{0} \mathrm{CF}_{\mathrm{t}-1}+\mathrm{b}_{1} \mathrm{CF}_{\mathrm{t}}+\mathrm{b}_{2} \mathrm{CF}_{\mathrm{t}+1}+\mathrm{c}_{0} \mathrm{ACC}_{\mathrm{t}-1}+\mathrm{c}_{1} \mathrm{ACC}_{\mathrm{t}}+\mathrm{c}_{2} \mathrm{ACC}_{\mathrm{t}+1}+\mathrm{b}_{3} \mathrm{R}_{\mathrm{t}+1}+\alpha \mathrm{D}_{\mathrm{t}}+$ $\beta_{0} D_{t} C F_{t-1}+\beta_{1} D_{t} C F_{t}+\beta_{2} D_{t} C F_{t+1}+\gamma_{0} D_{t} A_{C C} t-1+\gamma_{1} D_{t} A C_{t}+\gamma_{2} D_{t} A C_{t+1}+\beta_{3} D_{t} R_{t+1}+u_{t}$

where $D_{t}=($ rank-1)/(number of firms in industry-year -1$)$. Since higher values of the smoothing measures mean less smoothing, a positive (negative) $\beta_{2}$ means that firms with less (more) smoothing have higher FERC in (3) and FCFRC in (4), which implies that smoothing decreases (increases) stock price informativeness.

Although I am primarily interested in the coefficients on future earnings and cash flows, I include interactive coefficients on all of the regressors, thereby allowing all of the coefficients to vary with the degree of smoothing. If the other coefficients do vary with the degree of smoothing, but are constrained to be equal, any difference in FERC or FCFRC that I estimate

\footnotetext{
${ }^{14}$ I use 2 digit SIC codes in order to have enough observations per industry. My results are not sensitive to variation in the minimum industry observations condition. Lundholm and Myers (2002) also use this interactive percentile ranking method. I also conduct my tests by assigning firms to low, medium, and high smoothing groups, defined as bottom $25 \%$, middle $50 \%$, and top $25 \%$, for each industry year. I find similar results with this method. All regressions reported in the paper were also run with year dummies, which had virtually no effect on the results.
} 
might be due to the inappropriate restriction. On the other hand, if the coefficients on the other cash flow and accrual variables do not vary with smoothing, estimating additional parameters decreases the power of the test, which weakens my ability to find a relation between smoothing and informativeness.

I include in my sample all Compustat firms, including the Research File, in each year with the necessary data to construct the smoothing measures, returns, cash flow, and accrual variables. All fiscal years are included, but firms in financial and regulated industries are excluded (SIC codes 4000-4999 and 6000-6999) due to the special nature of their accounting.

\section{Primary Empirical Results}

Before running my main regressions, I conduct some preliminary tests. First, I want to "validate" that my smoothing measures actually capture income smoothing. Table 3 reports the results of regressions of current EPS on lagged EPS (both deflated by beginning of year share price) with an interaction term for the (within industry-year) percentile rank of the smoothing

measure: $\quad \mathrm{E}_{\mathrm{t}}=\mathrm{a}+\mathrm{D}_{\mathrm{t}}+\mathrm{b}_{0} \mathrm{E}_{\mathrm{t}-1}+\mathrm{b}_{1} \mathrm{D}_{\mathrm{t}} \mathrm{E}_{\mathrm{t}-1}+\mathrm{u}_{\mathrm{t}}$

In (5), the coefficient on lagged earnings is positively related to earnings persistence. Since a higher $\mathrm{D}_{\mathrm{t}}$ ranking means less smoothing, and thus less persistence, a valid smoothing measure should result in a negative $b_{1}$ coefficient. As Table 3 shows, this is exactly what I find. Interestingly, the coefficient on lagged earnings of approximately .5 implies that annual earnings are substantially mean-reverting, consistent with Ali and Zarowin (1991), and others.

Table 4 reports the results of regressions included to calibrate my results against prior research. Panel A shows pooled sample results of regression (1). As expected, the coefficients on $E_{t}$ and $E_{t+1}$ are positive, with $b_{1}>b_{2}$. Also as expected, the coefficients on $E_{t-1}$ and $R_{t+1}$ are 
negative. A ratio of $-b_{0} / b_{1}$ of about $1 / 2$ implies that annual earnings have large transitory components, consistent with the results in Table 3.

Panel B of Table 4 shows pooled sample results of regression (2). Again as predicted, the coefficients on the lagged, current, and future variables are negative, positive, and positive, respectively, with the current coefficient materially greater than the future one, and the lagged coefficient approximately $1 / 2$ the current one in absolute value. Contrary to Rayburn (1989), Bowen, Burghstaler, and Daley (1989), and Livnat and Zarowin (1990), these results reject the null hypothesis that the coefficients on current cash flows and accruals are equal $(\alpha<.01)$. These researchers, however, used changes in CFO and ACC as the regressors, thereby constraining the coefficients on the current and lagged variables to be equal, and they did not include future variables in the model. Interestingly, the coefficient on future accruals is greater than the coefficient on future cash flows, but the difference is small. Overall, the results for equations (1) and (2) are consistent with both prior research and our predictions.

Tables 5 and 6 report the results of regressions (3) and (4), which use earnings and cash flows, respectively, as the regressors. In both tables, the primary coefficient of interest is $\beta_{2}$; a positive (negative) $\beta_{2}$ means that firms with less (more) smoothing have higher FERC (Table 5) and FCFRC (Table 6), which implies that smoothing decreases (increases) stock price informativeness. In both tables, $\beta_{2}$ is significantly negative for both smoothing measures, indicating that increased smoothing is associated with increased stock price informativeness. Note in Table 5 that the coefficient on current earnings interacted with the smoothing measures, $\beta_{1} D_{t} E_{t}$, is negative. The negative coefficient is as expected, since a higher rank indicates less smoothing. Earnings that are less smooth are less persistent, and thus have a lower valuation 
coefficient. The results in Tables 5 and 6 are the first empirical evidence that more smoothing is associated with stock prices that reflect more information about future earnings and cash flows.

Positive residual serial correlation, which would cause the t-statistics (standard errors) to be overstated (understated) is a potential problem in the pooled regressions, since the smoothing measures use overlapping data. I believe that the problem is largely mitigated, since many of the firms in the sample, and their percentile ranks, change from year to year. However, to examine this issue, I estimated the correlation matrix of the annual series of residuals, and I found them to be quite small. For example, for regression (4), the mean correlations between the residuals from years $t$ and $t+1$ and between years $t$ and $t+2$ (estimates of the first and second order autocorrelations) are .029 and -.092 for the $\rho(\Delta \mathrm{ACC}, \Delta \mathrm{CFO})$ measure, and .031 and -.096 for the $\sigma_{\mathrm{NI}} / \sigma_{\mathrm{CFO}}$ measure, all of which are insignificantly different from zero. This indicates that residual auto-correlation is not a problem in the regressions, and thus the reported significance levels are accurate.

How can we be confident that the negative interactive coefficients on future earnings and cash flows in Tables 5 and 6 are not simply evidence of a persistence effect (since smoother earnings are more persistent, and thus have a higher valuation coefficient)? For the cash flow results in Table 6, smoothing works thru the management of accruals, not cash flows. Thus the coefficients on accruals, not the coefficients on cash flows, should be affected by smoothing. Consistent with this, the interactive coefficients on current (and future) accruals are negative. For the earnings results in Table 5, recall that the smoothing measures exclude the future year, in order to avoid inducing a relation between current returns and future earnings. For these reasons, I believe that the results in Tables 5 and 6 are not proxying for a persistence effect. 
Nevertheless, I include an additional test to examine the role of earnings persistence. It is well known that extreme earnings are less persistent, and thus have a lower contemporaneous ERC, than normal earnings. Constraining the contemporaneous ERC to be constant, as is done in Table 5, might bias the coefficient on future earnings downward, for firms with more extreme current earnings. Since these are firms with less smooth earnings, constraining the contemporaneous ERC to be constant might bias my results in favor of a negative smoothinginteractive coefficient. To test for this, Table 7 reports the results of regression (6), which controls for normal vs extreme contemporaneous earnings:

$$
\begin{aligned}
& R_{t}=a+b_{0} E_{t-1}+b_{1} E_{t}+b_{2} E_{t+1}+b_{3} R_{t+1}+\alpha D_{t}+\beta_{0} D_{t} E_{t-1}+\beta_{1} D_{t} E_{t}+\beta_{2} D_{t} E_{t+1}+\beta_{3} D_{t} R_{t+1}+ \\
& \Theta Z_{t}+\gamma_{0} Z_{t} E_{t-1}+\gamma_{1} Z_{t} E_{t}+\gamma_{2} Z_{t} E_{t+1}+\gamma_{3} Z_{t} R_{t+1}+u_{t}
\end{aligned}
$$

where $Z_{t}=0$ if $E_{t} / P_{t-1}$ is in the middle three quintiles for each industry year, and $Z_{t}=1$ if $E_{t} / P_{t-1}$ is in the top or bottom quintile for each industry year. The expected coefficient on $Z_{t} E_{t}$ is negative, which is exactly what is found in Table 7. Not surprisingly, the negative coefficient on $\mathrm{D}_{t} \mathrm{E}_{t}$ from Table 5 is attenuated when the $Z_{t}$ control is added in Table 7. Most important, however, the coefficient on $\mathrm{D}_{t} \mathrm{E}_{t+1}$, the smoothing interactive term, remains significantly negative. This increases our confidence that the previous results were not merely capturing a persistence effect.

In summary, the primary tests find that increased smoothing is associated with stock prices that reflect more information about both future earnings and future cash flows.

\section{Robustness Tests}

The industry-level cross-sectional approach requires that firms pooled together for the estimation of their smoothing measures be as homogeneous as possible. While pooling firms in the same industry is a natural first step in this direction, there could still be factors (such as 
timeliness of accounting data in reflecting information) that are related to both the smoothing measures and informativeness. In effect, these factors are potential correlated omitted variables in (3) and (4). To deal with these factors, we can explicitly include them as control variables in the regressions.

One such factor is cash flow volatility, which I measure as $\sigma_{\mathrm{CFO}}$. Greater cash flow volatility means that future cash flows are less persistent and harder to forecast, which would be reflected in a lower coefficient on $\mathrm{CF}_{\mathrm{t}+1}$ in Table 6. Ceteris paribus, greater cash flow volatility also causes the smoothing measure $\sigma_{\mathrm{NI}} / \sigma_{\mathrm{CFO}}$ to be lower, implying more smoothing. Since I find that smoothing is associated with greater informativeness, greater cash flow volatility should result in a positive $\beta_{2}$ interactive coefficient on $\mathrm{D}_{t} \mathrm{CF}_{\mathrm{t}+1}$ in (4), which is the opposite of what I find. Nevertheless, I include the within-industry year percentile ranking of cash flow volatility as an additional interactive variable, designated as $\mathrm{Z}_{\mathrm{t}}$, and I estimate the regression:

$$
\begin{gathered}
\mathrm{R}_{\mathrm{t}}=\mathrm{a}+\mathrm{b}_{0} \mathrm{CF}_{\mathrm{t}-1}+\mathrm{b}_{1} \mathrm{CF}_{\mathrm{t}}+\mathrm{b}_{2} \mathrm{CF}_{\mathrm{t}+1}+\mathrm{c}_{0} \mathrm{ACC}_{\mathrm{t}-1}+\mathrm{c}_{1} \mathrm{ACC}_{\mathrm{t}}+\mathrm{c}_{2} \mathrm{ACC}_{\mathrm{t}+1}+\mathrm{b}_{3} \mathrm{R}_{\mathrm{t}+1}+ \\
\alpha \mathrm{D}_{\mathrm{t}}+\beta_{0} \mathrm{D}_{\mathrm{t}} \mathrm{CF}_{\mathrm{t}-1}+\beta_{1} \mathrm{D}_{\mathrm{t}} \mathrm{CF}_{\mathrm{t}}+\beta_{2} \mathrm{D}_{\mathrm{t}} \mathrm{CF}_{\mathrm{t}+1}+\gamma_{0} \mathrm{D}_{\mathrm{t}} \mathrm{ACC}_{\mathrm{t}-1}+\gamma_{1} \mathrm{D}_{\mathrm{t}} \mathrm{ACC}_{\mathrm{t}}+\gamma_{2} \mathrm{D}_{\mathrm{t}} \mathrm{ACC}_{\mathrm{t}+1}+\beta_{3} \mathrm{D}_{\mathrm{t}} \mathrm{R}_{\mathrm{t}+1}+ \\
\alpha \mathrm{Z}_{\mathrm{t}}+\delta_{0} \mathrm{Z}_{\mathrm{t}} \mathrm{CF}_{\mathrm{t}-1}+\delta_{1} \mathrm{Z}_{\mathrm{t}} \mathrm{CF}_{\mathrm{t}}+\delta_{2} \mathrm{Z}_{\mathrm{t}} \mathrm{CF}_{\mathrm{t}+1}+\lambda_{0} \mathrm{Z}_{\mathrm{t}} \mathrm{ACC}_{\mathrm{t}-1}+\lambda_{1} \mathrm{Z}_{\mathrm{t}} \mathrm{ACC}_{\mathrm{t}}+\lambda_{2} \mathrm{Z}_{\mathrm{t}} \mathrm{ACC}_{\mathrm{t}+1}+\delta_{3} \mathrm{Z}_{\mathrm{t}} \mathrm{R}_{\mathrm{t}+1}+\mathrm{u}_{\mathrm{t}}
\end{gathered}
$$

The results of regression (7) are shown in Table 8. As expected, the $\delta_{2}$ coefficient on $\mathrm{Z}_{\mathrm{t}} \mathrm{CF}_{\mathrm{t}+1}$ is negative for both smoothing measures. More important for our purposes, $\beta_{2}$ remains negative for both smoothing measures, increasing our confidence that the previous results are not proxying for the effects of cash flow volatility.

Another potentially correlated omitted variable is size (market value of equity), which is a proxy for many things that can relate to timeliness and forecastability, such as risk and growth. As with cash flow volatility, the control variable is a within-industry year percentile ranking. The results are shown in Table 9. Again, regardless of the smoothing measure, $\beta_{2}$ is significantly 
negative. In summary, the results with the control variables show that the relation between smoothing and informativeness does not appear to be proxying for other correlated, omitted effects. $^{15}$

\section{Total Accruals vs Managed Accruals}

As discussed above, a problem with any test of earnings management is the inability to distinguish between managed vs unmanaged accruals. While our industry-year ranking method is a reasonable way to deal with this issue, it is still possible that our smoothing measures reflect primarily inherent accrual variation. In this case, the above results show that firms with smoother earnings, not firms with smoothed earnings, have greater informativeness.

To address this problem, I estimate the cross-sectional version of the Jones (1991) model:

$$
\underline{\operatorname{ACCRUALS}}_{\mathrm{t}}=\mathrm{a} \frac{1}{\operatorname{ASSETS}_{\mathrm{t}-1}}+\mathrm{b} \frac{\operatorname{CHSALES}_{\mathrm{t}}}{\operatorname{ASSETS}_{\mathrm{t}-1}}+\mathrm{c} \underset{\operatorname{ASPE}_{\mathrm{t}}}{\operatorname{PSSETS}_{\mathrm{t}-1}}+\mathrm{e}_{\mathrm{t}}
$$

Regression (8) decomposes total accruals into non-discretionary (fitted value) vs discretionary (residual) components, $\mathrm{ACC}^{\mathrm{e}}$ and $\mathrm{ACC}^{\mathrm{u}}$, respectively. Discretionary accruals estimated from (8), of course, is just a proxy for the "true" amount of earnings management, which is unobservable to the researcher (and perhaps to the market too). Like most of the recent literature on earnings

\footnotetext{
${ }^{15}$ The regressions in Tables 8 and 9 were also estimated with earnings as the regressor, and the the coefficient on the smoothing interactive term, $\beta_{2} \mathrm{D}_{t} \mathrm{E}_{t+1}$, was significantly negative with both smoothing measures. These results are not shown in the interest of brevity.

I also estimated the regressions with the control variables: 1. the within industry-year percentile ranking of the book-to-market ratio; 2. the sign of the current stock return (Basu [1997]). When earnings is the regressor, the coefficient on the smoothing interactive term, $\beta_{2} \mathrm{D}_{\mathrm{t}} \mathrm{E}_{\mathrm{t}+1}$, was significantly negative for each control and with each smoothing measure. When cash flows and accruals are the regressors, the coefficient on the smoothing interactive term, $\beta_{2} \mathrm{D}_{t} \mathrm{CF}_{\mathrm{t}+1}$, is significantly negative for each control when $\rho(\triangle \mathrm{ACC}, \Delta \mathrm{CFO})$ is the smoothing measure. When $\sigma_{\mathrm{N} /} / \sigma_{\mathrm{CFO}}$ is the smoothing measure, $\beta_{2} \mathrm{D}_{\mathrm{t}} \mathrm{CF}_{\mathrm{t}+1}$ is significantly negative at the .07 level (one tailed test) with the bookto-market control, and is insignificant with the sign-of-return control. These results are also not shown for brevity.
} 
management, I estimate (8) cross-sectionally by ( 2 digit) industry each year. Cross-sectional estimation allows for a large number of observations which increases the efficiency of parameter estimation. Estimation is by industry, since the relations among accruals, sales, and PPE should depend on the nature of the firm's operations. ${ }^{16}$

Using the accrual components estimated from (8), I define pre-discretionary income, $\mathrm{PDI}=\mathrm{CFO}+\mathrm{ACC}^{\mathrm{e}}$, and I calculate two measures of earnings management analogous to my two previous measures: (1) the correlation between (changes in) discretionary accruals and prediscretionary income, $\rho\left(\Delta \mathrm{ACC}^{\mathrm{u}}, \Delta \mathrm{PDI}\right)$; and (2) the standard deviation of net income relative to the standard deviation of pre-discretionary income, $\sigma_{\mathrm{NI}} / \sigma_{\mathrm{PDI}}$. These measures assume that there is an underlying pre-managed earnings, PDI, and that management uses discretionary accruals to smooth this figure into observed income.

Table 10 shows summary statistics for the estimation of the Jones model. Consistent with previous research, the mean and median coefficients on the change in sales and PPE are positive and negative, respectively. The sales coefficient is positive $75 \%$ of the time and the PPE coefficient is negative $97 \%$ of the time. The mean and median $\mathrm{R}^{2}$ are about $20 \%$ to $25 \%$.

The distributions (based on pooled data) of the Jones-based smoothing measures are similar to the distributions of the original measures. For example, $\rho\left(\Delta \mathrm{ACC}^{\mathrm{u}}, \Delta \mathrm{PDI}\right)$ has a mean and median of -.60 and -.91 , while $\sigma_{\mathrm{NI}} / \sigma_{\mathrm{PDI}}$ has a mean and median of 1.30 and .74 . The rank correlation between $\rho\left(\Delta \mathrm{ACC}^{\mathrm{u}}, \Delta \mathrm{PDI}\right)$ and $\rho(\Delta \mathrm{ACC}, \Delta \mathrm{CFO})$ is .79 , while the rank correlation between $\sigma_{\mathrm{NI}} / \sigma_{\mathrm{PDI}}$ and $\sigma_{\mathrm{NI}} / \sigma_{\mathrm{CFO}}$ is .87 .

\footnotetext{
${ }^{16}$ Bartov, Gul, and Tsui (2000) validate that the cross-sectional Jones model detects earnings management. As before, only industry-years with at least 30 observations are included in the analysis. Like Hwang and Ryan (2000), before running the Jones regression, I delete outliers defined as scaled cash flow or net income greater than three standard deviations from the annual industry mean.
} 
Table 11 shows the results of regression (3), with earnings as the regressor, using the two Jones-based smoothing measures. For both smoothing measures, the interactive coefficient on future earnings, $\beta_{2}$, is significantly negative, although the correlation measure yields stronger results. Table 12 shows the results of regression (4), with cash flows as the regressor, using the two Jones-based smoothing measures. When the correlation measure is used, the interactive coefficient on future cash flows, $\beta_{2}$, is significantly negative at the .10 level for a 2 -tailed test. When the standard deviation measure is used, however, $\beta_{2}$, is not significantly different from zero. Like in Table 11, the correlation measure yields stronger results. Overall, the results with the Jones-based measures, while not as strong as the original results, support the inference that smoothing is associated with more informative stock prices.

\section{Conclusion}

This paper examines the relation between income smoothing and the informativeness of stock prices. The relation between income smoothing and stock price informativeness is important for both academics and policymakers, because it relates to the perennial question of how much accounting discretion (i.e., ability to manage earnings) should firms have? As Schipper (1989) discusses, if managers smooth income to make stock prices more informative, this implies that financial reporting discretion is valuable.

Income smoothing is defined as the management of accruals to reduce time-series variation in income, and stock price informativeness is defined as the amount of information about future earnings or cash flows that is reflected in current period stock returns. I measure smoothing as the variation of net income relative to the variation in $\mathrm{CFO}$, or the correlation between changes in accruals and changes in CFO. I measure informativeness as the coefficient 
on future earnings (cash flows) in a regression of current stock return against current and future earnings (cash flows and accruals).

I regress current returns against current and future earnings or against current and future cash flows and accruals for firms with high vs low measures of income smoothing, and I compare the coefficients on the future earnings and cash flows. I find that firms with greater income smoothing have higher coefficients on both earnings and cash flows, implying that smoothing is associated with more informative stock prices.

Any test of earnings management, however, is a joint test of both the hypothesis in question and the measure of earnings management. This caveat is pertinent here, because discretionary smoothing behavior is unobservable, and an alternative interpretation of the results is that the smoothing measures might be capturing non-discretionary (inherent) smoothing. To address this issue, I decompose total accruals into estimates of their managed vs unmanaged components, using the cross-sectional version of the Jones (1991) model), and I construct smoothing measures based on managed accruals. While we can never completely rule out the alternative interpretation, the results with the Jones-based smoothing measures support the conclusion that smoothing is associated with more informative stock prices.

Thus, this paper presents the first empirical evidence that income smoothing is associated with more informative stock prices. Perhaps more important than its results, however, this paper presents a new approach to studying the effects of earnings management. The informativeness methodology used here to study income smoothing can be applied to other types of earnings management. This represents a promising area for future research. 


\section{References}

Ali, Ashiq and Paul Zarowin, 1991, "Permanent Versus Transitory Components of Annual Earnings and Estimation Error in Earnings Response Coefficients" Journal of Accounting and Economics, 249-264

Ayres, Benjamin and Robert Freeman, 2001, "Evidence that Analysts and Institutions Increase the Returns-Earnings Relationship", working paper, The University of Texas

Bartov, Eli, Ferdinand Gul, and Judy Tsui, 2000, "Discretionary Accruals Models and Audit Qualifications", Journal of Accounting and Economics, 421-452

Basu, Sudipta, 1997, "The Conservatism Principle and the Asymmetric Timeliness of Earnings", Journal of Accounting and Economics, 3-37

Bhattacharya, Utpal, Hazem Daouk, and Michael Welker, 2001, "The World Price of Earnings Opacity", working paper, University of Michigan

Bowen, Robert, David Burghstaler, and lane Daley, 1989, “The Incremental Information Content of Accruals Versus Cash Flows", The Accounting Review, 624-652

Burghstaler, David and I. Dichev, 1997, "Earnings Management to Avoid Earnings Decreases and Losses", Journal of Accounting and Economics, 99-126

Chaney, P.K. and C.M. Lewis, 1995, "Earnings Management and Firm Valuation Under Asymmetric Information", Journal of Corporate Finance: Contracting, Governance, and Organization, 319-345

Collins, Daniel W. and Paul Hribar, 1999, "Errors in Estimating Accruals: Implications for Empirical Research", working paper, University of Iowa

Collins, Daniel W., S. P. Kothari, Jay Shanken, and Richard Sloan, 1994, "Lack of Timeliness and Noise as Explanations for the Low Contemporaneous Return-Earnings Association," Journal of Accounting and Economics, 18, 289-324

DeAngelo, Harry, Linda DeAngelo, and Doug Skinner, 1994, “Accounting Choices of Troubled Companies", Journal of Accounting and Economics, 17, 113-143

DeFond Mark and James Jiambalvo, 1994, "Debt Covenant Effects and the Manipulation of Accruals", Journal of Accounting and Economics, 17,145-176

Defond, Mark and Chul W. Park, 1997, "Smoothing Income in Anticipation of Future Earnings", Journal of Accounting and Economics, 23, 115-139

DeGeorge, Francois, Jay Patel, and Richard Zeckhahser, 1999, "Earnings Management to Exceed Thresholds", Journal of Business, 1-33 
Durnev, Art, Randall Morck, Bernard Yeung, and Paul Zarowin, 2001, "Does Greater FirmSpecific Return Variation Mean More or Less Informed Stock Pricing?" working paper, New York University

Fama, Eugene, 1970, "Efficient Capital Markets: A Review of Theory and Empirical Work," Journal of Finance, 383-417.

Gelb, David and Paul Zarowin, 2002, "Corporate Disclosure Policy and the Informativeness of Stock Prices" Review of Accounting Studies, 33-52

Guay, Wayne, S.P. Kothari, and Ross Watts, 1996, “A Market-Based Evaluation of Discretionary Accruals Models", Journal of Accounting Research, 83-105

Hand, John, 1989, "Did Firms Undertake Debt-Equity Swaps for an Accounting Paper Profit or a True Financial Gain", The Accounting Review, 587-623

Healy, Paul and James Wahlen, 2000, "A Review of the Earnings Management Literature and Its Implications for Standard Setting”, Accounting Horizons, 365-383

Hunt, Alister, Susan Moyer, and Terry Shevlin, 2000, "Earnings Volatility, Earnings Management, and Equity Value", working paper, University of Washington

Hwang, Lee-Seok and Stephen Ryan, 2000, "The Varied Nature and Pricing Implications of Discretionary Behavior: Big Baths, Loss Avoidance, and Sugarbowling”, working paper, New York University

Jiambalvo, James S. Rajgopal, and M. Venkatachalam, 2002, "Institutional ownership and the Extent to Which Stock Prices Reflect Future Earnings", Contemporary Accounting Research, Spring

Jones, Jennifer, 1991, "Earnings Management During Import relief Investigations", Journal of Accounting Research, 193-228

Kothari, S. P., Andrew Leone, and Charles Wasley, 2001, "Performance Matched Discretionary Accruals", working paper, University of Rochester

Leuz, Christian, Dhananjay Nanda, and Peter Wysocki, 2001, "Investor Protection and Earnings Management", working paper, University of Pennsylvania

Levitt, Arthur, 1998, "The Numbers game”, Speech delivered at NYU Center for Law and Business, New York, N.Y., September 28

Livnat, Joshua and Paul Zarowin, 1990,“The Incremental Information Content of Cash Flow Components" Journal of Accounting and Economics, 25-46 
Lundholm, Russell and Linda Myers, 2002, "Bringing the Future Forward: The Effect of Disclosure on the Returns-Earnings Relation", Journal of Accounting Research, forthcoming

Kirschenheiter, Michael and Nahum Melumad, 2002, "Earnings Quality and Smoothing", working paper, Columbia University

Myers, Linda and Douglas Skinner, 1999, "Earnings Momentum and Earnings Management", working paper, University of Michigan

Ohlson, James A., 1995, "Earnings, Book Values, and Dividends in Equity Valuation”, Contemporary Accounting Research, 661-688

Joseph Piotroski and Darren Roulstone, 2002, "Informed Traders and the Incorporation of Industry and Firm-Specific Information into Stock Prices", working paper, University of Chicago

Rayburn, Judy, 1986, "The Association of Operating Cash Flows and Accruals With Security Returns", Journal of Accounting Research, 112-138

Ronen, Joshua and S.Sadan, 1981, Smoothing Income Numbers: Objectives, Means, and Implications Reading, Mass. Addison-Wesley

Schipper, Katherine, 1989, "Earnings Management", Accounting Horizons, 3, 91-106

Subramanyam, K. R. 1996, "The Pricing of Discretionary Accruals", Journal of Accounting and Economics, 22, 249-281

Teoh, S., I. Welch, and T. J. Wong, 1998, "Earnings Management and the Post-Issue Performance of Seasoned Equity Offerings", Journal of Financial Economics, 50, 63-99

Teoh, S., T. J. Wong, , and G. Rao, 1998, “Are Accruals During Initial Public Offerings Opportunistic", Review of Accounting Studies, 3, 175-208

Tobin, James, 1982, “On the Efficiency of the Financial System”, Lloyd's Banking Review, July 


\section{Table 1}

Pooled Sample Statistics, 1991 - 1999

\begin{tabular}{|c|c|c|c|c|c|}
\hline Variable & Mean & $\underline{\text { Std Dev }}$ & Median & $\underline{\text { Min }}$ & $\underline{\text { Max }}$ \\
\hline$\overline{\mathrm{R}_{\mathrm{t}}}$ & $\overline{.164}$ & $\begin{array}{l}.727 \\
\end{array}$ & $\begin{array}{c}.038 \\
\end{array}$ & $\overline{-.919}$ & $\overline{10.00}$ \\
\hline $\mathrm{E}_{\mathrm{t}} / \mathrm{P}_{\mathrm{t}-1}$ & -.004 & .174 & .041 & -2.43 & .474 \\
\hline$\rho(\Delta \mathrm{ACC}, \Delta \mathrm{CFO}$ & D) -.622 & .579 & _.926 & _1.00 & 1.00 \\
\hline$\sigma_{\mathrm{NI}} / \sigma_{\mathrm{CFO}}$ & 1.435 & 2.853 & .816 & .003 & 124.8 \\
\hline $\mathrm{ACC}_{\mathrm{t}} / \mathrm{P}_{\mathrm{t}-1}$ & _.088 & .196 & _.043 & -4.32 & .558 \\
\hline $\mathrm{CF}_{\mathrm{t}} / \mathrm{P}_{\mathrm{t}-1}$ & .084 & .167 & .074 & _.889 & 2.024 \\
\hline $\begin{array}{l}\mathrm{B}_{\mathrm{t}-1} / \mathrm{M}_{\mathrm{t}-1} \\
(\mathrm{n}=24,057)\end{array}$ & .84 & 1.418 & .581 & _11.474 & 60.84 \\
\hline
\end{tabular}

Notes

$R_{t}$ is the current annual stock return.

$E_{t} / P_{t-1}$ is current annual earnings per share $\div$ beginning of year share price.

$\rho(\triangle A C C, \triangle C F O)$ is the correlation between annual changes in accruals and annual changes in $\mathrm{CFO}$, computed using ACC and $\mathrm{CFO}$ from $\mathrm{t}-4$ thru $\mathrm{t}-1$, where each observation is deflated by beginning of year total assets.

$\sigma_{N I} / \sigma_{C F O}$ is the standard deviation of net income $\div$ the standard deviation of CFO, computed using ACC and $\mathrm{CFO}$ from $\mathrm{t}-3$ thru $\mathrm{t}-1$, where each observation is deflated by beginning of year total assets.

$A C C_{t} / P_{t-1}$ and $C F_{t} / P_{t-1}$ are current annual accruals and CFO per share $\div$ beginning of year share price. $B_{t-1} / M_{t-1}$ is the book-to-market ratio at the beginning of the year. 
Table 2

\begin{tabular}{|c|c|c|c|c|c|c|c|}
\hline \multicolumn{8}{|c|}{ Correlations } \\
\hline & $\mathrm{R}_{\mathrm{t}}$ & $\mathrm{E}_{\mathrm{t}} / \mathrm{P}_{\mathrm{t}-1}$ & $\rho(\Delta \mathrm{ACC}, \Delta \mathrm{CFO})$ & $\sigma_{\mathrm{NI}} / \sigma_{\mathrm{CFO}}$ & $\mathrm{ACC}_{\mathrm{t}} / \mathrm{P}_{\mathrm{t}}$ & $\mathrm{CF}_{\mathrm{t}} / \mathrm{P}_{\mathrm{t}-1}$ & $\mathrm{~B}_{\mathrm{t}-1} / \mathrm{M}_{\mathrm{t}-1}$ \\
\hline $\mathrm{R}_{\mathrm{t}}$ & 1.0 & .187 & .014 & -.009 & .065 & .118 & .111 \\
\hline $\mathrm{E}_{\mathrm{t}} / \mathrm{P}_{\mathrm{t}-1}$ & .418 & 1.0 & -.149 & -.167 & .601 & .336 & .079 \\
\hline$\rho(\triangle \mathrm{ACC}, \Delta \mathrm{CFO})$ & -.061 & -.220 & 1.0 & .220 & -.053 & -.093 & -.062 \\
\hline$\sigma_{\mathrm{NI}} / \sigma_{\mathrm{CFO}}$ & -.103 & -.299 & .471 & 1.0 & -.089 & -.070 & -.046 \\
\hline $\mathrm{ACC}_{\mathrm{t}} / \mathrm{P}_{\mathrm{t}-1}$ & .071 & .256 & -.085 & -.114 & 1.0 & -.551 & -.102 \\
\hline $\mathrm{CF}_{\mathrm{t}} / \mathrm{P}_{\mathrm{t}-1}$ & .234 & .499 & -.117 & -.154 & -.574 & 1.0 & .202 \\
\hline $\mathrm{B}_{\mathrm{t}-1} / \mathrm{M}_{\mathrm{t}-1}$ & .236 & .271 & -.153 & -.178 & -.209 & .375 & 1.0 \\
\hline
\end{tabular}

$\underline{\text { Notes }}$

See notes to Table 1 for variable definitions. Pearson (Spearman rank) correlations are above (below) the diagonal. 


\section{Table 3}

Regressions of current earnings against lagged earnings and interactions with smoothing measures, 1991 - 1999

$$
E_{t}=a+D_{t}+b_{0} E_{t-1}+b_{1} D_{t} E_{t-1}+u_{t} \quad R^{2}
$$

$\underline{\text { Panel A }}$

smoothing measure is $\rho(\Delta \mathrm{ACC}, \Delta \mathrm{CFO})$

$$
\begin{array}{cccc}
.030 & -.052 & .469 & -.257 \\
(14.73) & (-15.18) & (48.61) & (-18.26) \\
& & \\
& & \text { Panel B } &
\end{array}
$$

smoothing measure is $\sigma_{\mathrm{NI}} / \sigma_{\mathrm{CFO}}$

$$
\begin{array}{cccc}
.048 & -.097 & .573 & -.398 \\
(26.04) & (-30.46) & (52.46) & (-27.27)
\end{array}
$$

\section{Notes}

See Table 1 for variable definitions. Numbers under the variables are coefficients (and t-statistics in parentheses).

$\mathrm{D}_{\mathrm{t}}$ is a percentile ranking of the smoothing measure within each firm's ( 2 digit SIC code) industry-year: $D_{t}=($ rank-1) $/($ number of firms in industry-year -1$)$. 


\section{Table 4}

Regression Results, 1991 - 1999

$\underline{\text { Panel A }}$

Regressions of Returns against lagged, current, and future earnings

$$
\begin{aligned}
& \mathrm{R}_{\mathrm{t}}=\mathrm{a}+\mathrm{b}_{0} \mathrm{E}_{\mathrm{t}-1}+\mathrm{b}_{1} \mathrm{E}_{\mathrm{t}}+\mathrm{b}_{2} \mathrm{E}_{\mathrm{t}+1}+\mathrm{b}_{3} \mathrm{R}_{\mathrm{t}+1}+\mathrm{u}_{\mathrm{t}} \mathrm{R}^{2} \\
& \begin{array}{llllll}
.167 & -.444 & .928 & .278 & -.082 & .060
\end{array} \\
& \begin{array}{lllll}
(35.69) & (-21.35) & (29.02) & (9.2) & (-13.84)
\end{array}
\end{aligned}
$$

\section{Panel B}

Regressions of Returns against lagged, current, and future cash flows and accruals

$$
\begin{array}{cccccccc}
\mathrm{R}_{\mathrm{t}}=\mathrm{a}+\mathrm{b}_{0} \mathrm{CF}_{\mathrm{t}-1} & +\mathrm{b}_{1} \mathrm{CF}_{\mathrm{t}} & +\mathrm{b}_{2} \mathrm{CF}_{\mathrm{t}+1} & +\mathrm{c}_{0} \mathrm{ACC}_{\mathrm{t}-1} & +\mathrm{c}_{1} \mathrm{ACC}_{\mathrm{t}}+\mathrm{c}_{2} \mathrm{ACC}_{\mathrm{t}+1}+\mathrm{b}_{3} \mathrm{R}_{\mathrm{t}+1}+\mathrm{u}_{\mathrm{t}} & \mathrm{R}^{2} \\
.149 & -.451 & 1.134 & .214 & -.437 & .860 & .252 & -.082 \\
(26.74)(-13.56) & (27.22) & (5.61) & (-20.50) & (26.15) & (7.79) & (-14.01) &
\end{array}
$$

\section{$\underline{\text { Notes }}$}

See Table 1 for variable definitions. Numbers under the variables are coefficients (and t-statistics in parentheses). 


\section{Table 5}

Regressions of Returns against lagged, current, and future earnings, and interactions with smoothing measures, 1991 - 1999

\section{Panel A}

Smoothing Measure is $\rho(\Delta \mathrm{ACC}, \Delta \mathrm{CFO})$

$$
\begin{aligned}
& R_{t}=a+b_{0} E_{t-1}+b_{1} E_{t}+b_{2} E_{t+1}+b_{3} R_{t+1}+\alpha D_{t}+\beta_{0} D_{t} E_{t-1}+\beta_{1} D_{t} E_{t}+\beta_{2} D_{t} E_{t+1}+\beta_{3} D_{t} R_{t+1}+u_{t} \\
& \begin{array}{llllllllll}
.145 & -.403 & 1.048 & .543 & -.062 & .036 & -.064 & -.189 & -.481 & -.036
\end{array} \\
& \begin{array}{llllllllll}
(15.19) & (-7.77) & (13.53) & (8.27) & (-4.73) & (2.20) & (-0.87) & (-1.66) & (-4.65) & (-1.76)
\end{array} \\
& \mathrm{R}^{2}=.062
\end{aligned}
$$

\section{$\underline{\text { Panel B }}$}

Smoothing Measure is $\sigma_{\mathrm{NI}} / \sigma_{\mathrm{CFO}}$

$$
\begin{aligned}
& R_{t}=a+b_{0} E_{t-1}+b_{1} E_{t}+b_{2} E_{t+1}+b_{3} R_{t+1}+\alpha D_{t}+\beta_{0} D_{t} E_{t-1}+\beta_{1} D_{t} E_{t}+\beta_{2} D_{t} E_{t+1}+\beta_{3} D_{t} R_{t+1}+u_{t}
\end{aligned}
$$

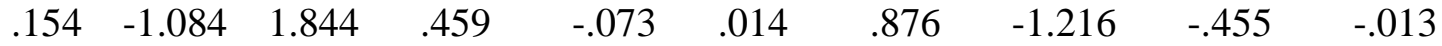

$$
\begin{aligned}
& \begin{array}{lllllllll}
(16.49) & (-16.29)(18.71) & (6.83) & (-5.81) & (0.88) & (10.25) & (-9.62) & (-4.47) & (-0.66)
\end{array} \\
& \mathrm{R}^{2}=.058
\end{aligned}
$$

\section{Notes}

See Tables 1 and 3 for variable definitions. Numbers under the variables are coefficients (and t-statistics in parentheses). 


\section{Table 6}

Regressions of Returns against lagged, current, and future cash flows and accruals, and interactions with smoothing measures, 1991 - 1999

\section{Panel A}

Smoothing Measure is $\rho(\Delta \mathrm{ACC}, \Delta \mathrm{CFO})$

\begin{tabular}{|c|c|c|c|c|c|c|c|c|}
\hline $\begin{array}{c}\mathrm{R}_{\mathrm{t}}=\mathrm{a}+ \\
.128 \\
(11.12)\end{array}$ & $\begin{array}{l}\mathrm{b}_{0} \mathrm{CF}_{\mathrm{t}-1} \\
-.240 \\
(-3.14)\end{array}$ & $\begin{array}{c}+\mathrm{b}_{1} \mathrm{CF}_{\mathrm{t}} \\
1.136 \\
(11.90)\end{array}$ & $\begin{array}{l}\mathrm{b}_{2} \mathrm{CF}_{\mathrm{t}+1} \\
.437 \\
(5.26)\end{array}$ & $\begin{array}{c}+\mathrm{c}_{0} \mathrm{ACC}_{\mathrm{t}-1} \\
-.417 \\
(-7.97)\end{array}$ & $\begin{array}{c}+\mathrm{c}_{1} \mathrm{ACC}_{\mathrm{t}} \\
.993 \\
(12.63)\end{array}$ & $\begin{aligned}+\mathrm{c}_{2} \mathrm{ACC}_{\mathrm{t}+1} \\
.541 \\
(7.83)\end{aligned}$ & $\begin{array}{l}+\mathrm{b}_{3} \mathrm{R}_{\mathrm{t}+1} \\
-.064 \\
(-4.87)\end{array}$ & + \\
\hline $\begin{array}{c}\alpha \mathrm{D}_{\mathrm{t}}+ \\
.032 \\
(1.66)\end{array}$ & $\begin{array}{l}\beta_{0} \mathrm{D}_{\mathrm{t}} \mathrm{CF}_{\mathrm{t}-1} \\
-.394 \\
(-3.28)\end{array}$ & $\begin{array}{c}+\beta_{1} \mathrm{D}_{\mathrm{t}} \mathrm{CF}_{\mathrm{t}} \\
.042 \\
(0.28)\end{array}$ & $\begin{array}{c}+\beta_{2} \mathrm{D}_{\mathrm{t}} \mathrm{CF}_{\mathrm{t}+1} \\
-.394 \\
(-2.94)\end{array}$ & $\begin{array}{c}+\gamma_{0} \mathrm{D}_{\mathrm{t}} \mathrm{ACC}_{\mathrm{t}-1} \\
-.013 \\
(-0.18)\end{array}$ & $\begin{array}{r}+\gamma_{1} \mathrm{D}_{\mathrm{t}} \mathrm{ACC} \\
-.222 \\
(-1.91)\end{array}$ & $\begin{array}{c}+\gamma_{2} \mathrm{D}_{\mathrm{t}} \mathrm{ACC}_{\mathrm{t}+1} \\
-.534 \\
(-4.83)\end{array}$ & $\begin{aligned}+ & \beta_{3} \mathrm{D}_{\mathrm{t}} \mathrm{R}_{\mathrm{t}+1} \\
& -.034 \\
& (-1.68)\end{aligned}$ & \\
\hline
\end{tabular}

\section{$\underline{\text { Panel B }}$}

Smoothing Measure is $\sigma_{\mathrm{NI}} / \sigma_{\mathrm{CFO}}$

\begin{tabular}{|c|c|c|c|c|c|c|c|c|c|}
\hline $\begin{array}{c}\mathrm{R}_{\mathrm{t}}=\mathrm{a}+ \\
.141 \\
(12.80)\end{array}$ & $\begin{array}{c}\mathrm{b}_{0} \mathrm{CF}_{\mathrm{t}-1} \\
-.926 \\
(-11.36)\end{array}$ & $\begin{array}{c}+\mathrm{b}_{1} \mathrm{CF}_{\mathrm{t}} \\
1.887 \\
(17.56)\end{array}$ & + & $\begin{array}{l}\mathrm{b}_{2} \mathrm{CF}_{\mathrm{t}+1} \\
.322 \\
(4.02)\end{array}$ & $\begin{array}{c}+\mathrm{c}_{0} \mathrm{ACC}_{\mathrm{t}-1} \\
-1.051 \\
(-15.43)\end{array}$ & $\begin{aligned}+ & \mathrm{c}_{1} \mathrm{ACC}_{\mathrm{t}} \\
& 1.666 \\
& (16.29)\end{aligned}$ & $\begin{array}{c}+\mathrm{c}_{2} \mathrm{ACC}_{\mathrm{t}+1} \\
.479 \\
(6.83)\end{array}$ & $\begin{array}{c}+b_{3} R_{t+1} \\
-.075 \\
(-5.95)\end{array}$ & + \\
\hline $\begin{array}{l}\alpha \mathrm{D}_{\mathrm{t}}+ \\
.020 \\
(1.08)\end{array}$ & $\begin{array}{c}\beta_{0} \mathrm{D}_{\mathrm{t}} \mathrm{CF}_{\mathrm{t}-1} \\
.537 \\
(4.18)\end{array}$ & $\begin{array}{c}+\beta_{1} \mathrm{D}_{\mathrm{t}} \mathrm{CF}_{\mathrm{t}} \\
-1.059 \\
(-6.49)\end{array}$ & & $\begin{array}{c}\beta_{2} \mathrm{D}_{\mathrm{t}} \mathrm{CF}_{\mathrm{t}+1} \\
-.277 \\
(-2.16)\end{array}$ & $\begin{array}{c}+\gamma_{0} \mathrm{D}_{\mathrm{t}} \mathrm{ACC}_{\mathrm{t}-1} \\
.855 \\
(9.83)\end{array}$ & $\begin{array}{c}+\gamma_{1} \mathrm{D}_{\mathrm{t}} \mathrm{ACC} \\
-1.039 \\
(-8.00)\end{array}$ & $\begin{array}{c}\gamma_{2} \mathrm{D}_{\mathrm{t}} \mathrm{ACC}_{\mathrm{t}+1} \\
-.502 \\
(-4.69)\end{array}$ & $\begin{aligned}+ & \beta_{3} \mathrm{D}_{\mathrm{t}} \mathrm{R}_{\mathrm{t}+1} \\
& -.011 \\
& (-0.53)\end{aligned}$ & \\
\hline
\end{tabular}

\section{$\underline{\text { Notes }}$}

See Tables 1 and 3 for variable definitions. Numbers under the variables are coefficients (and t-statistics in parentheses). 


\section{Table 7}

Regressions of Returns against lagged, current, and future earnings, and interactions with smoothing measures, and control for extreme earnings,1991 - 1999

\section{Panel A}

Smoothing Measure is $\rho(\Delta \mathrm{ACC}, \Delta \mathrm{CFO})$

$$
\begin{aligned}
& R_{t}=a+b_{0} E_{t-1}+b_{1} E_{t}+b_{2} E_{t+1}+b_{3} R_{t+1}+\alpha D_{t}+\beta_{0} D_{t} E_{t-1}+\beta_{1} D_{t} E_{t}+\beta_{2} D_{t} E_{t+1}+\beta_{3} D_{t} R_{t+1}+
\end{aligned}
$$

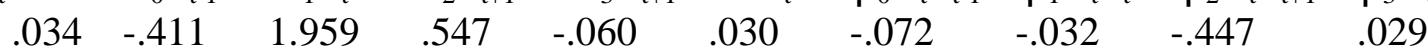

$$
\begin{aligned}
& \begin{array}{llllllllll}
(3.19) & (-7.20) & (13.36) & (7.16) & (-4.38) & (1.83) & (-0.99) & (-0.28) & (-4.36) & (-1.47)
\end{array}
\end{aligned}
$$

$\mathrm{R}^{2}=.086$

$$
\begin{array}{ccccc}
\Theta \mathrm{Z}_{\mathrm{t}}+\gamma_{0} \mathrm{Z}_{\mathrm{t}} \mathrm{E}_{\mathrm{t}-1}+\gamma_{1} \mathrm{Z}_{\mathrm{t}} \mathrm{E}_{\mathrm{t}}+\gamma_{2} \mathrm{Z}_{\mathrm{t}} \mathrm{E}_{\mathrm{t}+1}+\gamma_{3} \mathrm{Z}_{\mathrm{t}} \mathrm{R}_{\mathrm{t}+1}+\mathrm{u}_{\mathrm{t}} \\
.250 & .062 & -.905 & -.104 & -.010 \\
(24.46) & (1.38) & (-6.58) & (-1.60) & (-0.86)
\end{array}
$$

\section{Panel B}

Smoothing Measure is $\sigma_{\mathrm{NI}} / \sigma_{\mathrm{CFO}}$

$$
\begin{array}{cccccccccc}
\mathrm{R}_{\mathrm{t}}=\mathrm{a}+\mathrm{b}_{0} \mathrm{E}_{\mathrm{t}-1}+\mathrm{b}_{1} \mathrm{E}_{\mathrm{t}}+\mathrm{b}_{2} \mathrm{E}_{\mathrm{t}+1}+\mathrm{b}_{3} \mathrm{R}_{\mathrm{t}+1}+\alpha \mathrm{D}_{\mathrm{t}}+\beta_{0} \mathrm{D}_{\mathrm{t}} \mathrm{E}_{\mathrm{t}-1}+\beta_{1} \mathrm{D}_{\mathrm{t}} \mathrm{E}_{\mathrm{t}}+\beta_{2} \mathrm{D}_{\mathrm{t}} \mathrm{E}_{\mathrm{t}+1}+\beta_{3} \mathrm{D}_{\mathrm{t}} \mathrm{R}_{\mathrm{t}+1}+ \\
.068 & -1.010 & 2.274 & .464 & -.070 & -.009 & .784 & -.870 & -.368 & -.008 \\
(6.64) & (-14.14) & (15.67) & (6.25) & (-5.44) & (-0.58) & (9.26) & (-6.83) & (-3.61) & (-0.38)
\end{array}
$$

$\mathrm{R}^{2}=.078$

$$
\begin{array}{ccccc}
\Theta \mathrm{Z}_{\mathrm{t}}+\gamma_{0} \mathrm{Z}_{\mathrm{t}} \mathrm{E}_{\mathrm{t}-1}+\gamma_{1} \mathrm{Z}_{\mathrm{t}} \mathrm{E}_{\mathrm{t}}+\gamma_{2} \mathrm{Z}_{\mathrm{t}} \mathrm{E}_{\mathrm{t}+1}+\gamma_{3} \mathrm{Z}_{\mathrm{t}} \mathrm{R}_{\mathrm{t}+1}+\mathrm{u}_{\mathrm{t}} \\
.232 & .041 & -.581 & -.127 & -.014 \\
(23.98) & (0.98) & (-4.56) & (-2.06) & (-1.24)
\end{array}
$$

Notes

See Tables 1 and 3 for variable definitions. Numbers under the variables are coefficients (and t-statistics in parentheses). $Z_{t}=0$ if $E_{t} / P_{t-1}$ is in the middle three quintiles for each industry year, and $Z_{t}=1$ if $\mathrm{E}_{\mathrm{t}} / \mathrm{P}_{\mathrm{t}-1}$ is in the top or bottom quintile for each industry year. 


\section{Table 8}

Regressions of Returns against lagged, current, and future cash flows and accruals, and interactions with smoothing measures and with cash flow volatility, 1991 - 1999

\section{Panel A}

Smoothing Measure is $\rho(\Delta \mathrm{ACC}, \Delta \mathrm{CFO})$

$$
\begin{aligned}
& \begin{array}{cccccccc}
\mathrm{R}_{\mathrm{t}}=\mathrm{a}+ & \mathrm{b}_{0} \mathrm{CF}_{\mathrm{t}-1} & +\mathrm{b}_{1} \mathrm{CF}_{\mathrm{t}}+ & \mathrm{b}_{2} \mathrm{CF}_{\mathrm{t}+1} & +\mathrm{c}_{0} \mathrm{ACC}_{\mathrm{t}-1} & +\mathrm{c}_{1} \mathrm{ACC}_{\mathrm{t}} & +\mathrm{c}_{2} \mathrm{ACC}_{\mathrm{t}+1} & +\mathrm{b}_{3} \mathrm{R}_{\mathrm{t}+1}+ \\
.059 & -.361 & 1.349 & .796 & -.555 & 1.024 & .937 & -.068 \\
(3.73) & (-2.76) & (8.76) & (6.61) & (-6.82) & (9.19) & (9.49) & (-3.82)
\end{array} \\
& \alpha D_{t}+\beta_{0} D_{t} C F_{t-1}+\beta_{1} D_{t} C F_{t}+\beta_{2} D_{t} C F_{t+1}+\gamma_{0} D_{t} A_{C C} t-1+\gamma_{1} D_{t} A C C C_{t}+\gamma_{2} D_{t} A C C_{t+1}+\beta_{3} D_{t} R_{t+1}+ \\
& \begin{array}{llllllll}
.028 & -.343 & .044 & -.427 & .035 & -.261 & -.572 & -.032
\end{array} \\
& \begin{array}{lllllll}
(1.43) & (-2.83) & (0.29) & (-3.16) & (0.44) & (-2.21) & (-5.13)
\end{array}
\end{aligned}
$$

\begin{tabular}{|c|c|c|c|c|c|c|c|}
\hline $\begin{array}{c}\mathrm{R}_{\mathrm{t}}=\mathrm{a}+ \\
.026 \\
(1.49)\end{array}$ & $\begin{array}{c}\mathrm{b}_{0} \mathrm{CF}_{\mathrm{t}-1} \\
-1.531 \\
(-10.10)\end{array}$ & $\begin{array}{c}+\mathrm{b}_{1} \mathrm{CF}_{\mathrm{t}}+ \\
2.662 \\
(14.22)\end{array}$ & $\begin{array}{l}\mathrm{b}_{2} \mathrm{CF}_{\mathrm{t}+1} \\
.905 \\
(6.71)\end{array}$ & $\begin{array}{l}+\mathrm{c}_{0} \mathrm{ACC} \mathrm{C}_{\mathrm{t}-1} \\
-1.898 \\
(-16.38)\end{array}$ & $\begin{array}{l}+\mathrm{c}_{1} \mathrm{ACC}_{\mathrm{t}} \\
2.282 \\
(14.45)\end{array}$ & $\begin{array}{c}+\mathrm{c}_{2} \mathrm{ACC}_{\mathrm{t}+1} \\
1.139 \\
(9.86)\end{array}$ & $\begin{array}{l}+b_{3} R_{t+1}+ \\
-.082 \\
(-4.07)\end{array}$ \\
\hline $\begin{array}{l}\alpha \mathrm{D}_{\mathrm{t}}+ \\
.070 \\
(3.63)\end{array}$ & $\begin{array}{c}\beta_{0} \mathrm{D}_{\mathrm{t}} \mathrm{CF}_{\mathrm{t}-1} \\
.887 \\
(6.37)\end{array}$ & $\begin{array}{c}+\beta_{1} \mathrm{D}_{\mathrm{t}} \mathrm{CF}_{\mathrm{t}}+ \\
-1.462 \\
(-8.24)\end{array}$ & $\begin{array}{l}\beta_{2} \mathrm{D}_{\mathrm{t}} \mathrm{CF}_{\mathrm{t}+1} \\
-.544 \\
(-3.94)\end{array}$ & $\begin{array}{c}\gamma_{0} \mathrm{D}_{\mathrm{t}} \mathrm{ACC}_{\mathrm{t}-1} \\
1.381 \\
(13.19)\end{array}$ & $\begin{array}{c}+\gamma_{1} \mathrm{D}_{\mathrm{t}} \mathrm{ACC}_{\mathrm{t}} \\
-1.469 \\
(-10.00)\end{array}$ & $\begin{array}{c}+\gamma_{2} \mathrm{D}_{\mathrm{t}} \mathrm{ACC}_{\mathrm{t}+1}- \\
-.816 \\
(-7.05)\end{array}$ & $\begin{aligned}+ & \beta_{3} D_{t} R_{t+1}+ \\
& -.007 \\
& (-0.36)\end{aligned}$ \\
\hline $\begin{array}{l}\alpha Z_{t}+ \\
.148 \\
(7.85)\end{array}$ & $\begin{array}{l}\delta_{0} \mathrm{Z}_{\mathrm{t}} \mathrm{CF}_{\mathrm{t}-1} \\
.542 \\
(3.93)\end{array}$ & $\begin{array}{c}+\delta_{1} \mathrm{Z}_{\mathrm{t}} \mathrm{CF}_{\mathrm{t}}+ \\
-.643 \\
(-3.83)\end{array}$ & $\begin{array}{l}\delta_{2} Z_{t} C F_{t+1} \\
-.754 \\
(-5.39)\end{array}$ & $\begin{array}{c}+\lambda_{0} \mathrm{Z}_{\mathrm{t}} \mathrm{ACC}_{\mathrm{t}-1} \\
.794 \\
(9.35)\end{array}$ & $\begin{array}{c}+\lambda_{1} \mathrm{Z}_{\mathrm{t}} \mathrm{ACC}_{\mathrm{t}} \\
-.403 \\
+(-3.31)\end{array}$ & $\begin{array}{c}+\lambda_{2} \mathrm{Z}_{\mathrm{t}} \mathrm{ACC}_{\mathrm{t}+1} \\
-.845 \\
(-7.07)\end{array}$ & $\begin{array}{c}+\delta_{3} Z_{t} R_{t+1}+u_{t} \\
.009 \\
(0.43)\end{array}$ \\
\hline
\end{tabular}

$\begin{array}{llllllll}.122 & .151 & -.255 & -.585 & .196 & .005 & -.655 & .004 \\ (6.30) & (1.08) & (-1.51) & (-4.20) & (2.43) & (0.04) & (-5.47) & (0.17)\end{array}$

$\mathrm{R}^{2}=.068$

$\underline{\text { Panel B }}$

Smoothing Measure is $\sigma_{\mathrm{NI}} / \sigma_{\mathrm{CFO}}$

$\mathrm{R}^{2}=.067$

Notes

See Tables 1 and 3 for variable definitions. Numbers under the variables are coefficients (and t-statistics in parentheses). $Z_{t}$ is a percentile ranking of cash flow volatility $\left(\sigma_{\mathrm{CFO}}\right)$ within each firm's (2 digit SIC code) industry-year: $Z_{t}=($ rank-1)/(number of firms in industry-year -1$)$. 


\section{Table 9}

Regressions of Returns against lagged, current, and future cash flows and accruals, and interactions with smoothing measures and with market value of equity, 1991 - 1999

\section{Panel A}

Smoothing Measure is $\rho(\Delta \mathrm{ACC}, \Delta \mathrm{CFO})$

$$
\begin{aligned}
& \begin{array}{cccccccc}
\mathrm{R}_{\mathrm{t}}=\mathrm{a}+ & \mathrm{b}_{0} \mathrm{CF}_{\mathrm{t}-1} & +\mathrm{b}_{1} \mathrm{CF}_{\mathrm{t}}+ & \mathrm{b}_{2} \mathrm{CF}_{\mathrm{t}+1} & +\mathrm{c}_{0} \mathrm{ACC}_{\mathrm{t}-1} & +\mathrm{c}_{1} \mathrm{ACC}_{\mathrm{t}} & +\mathrm{c}_{2} \mathrm{ACC}_{\mathrm{t}+1} & +\mathrm{b}_{3} \mathrm{R}_{\mathrm{t}+1}+ \\
-.050 & -.144 & .908 & -.173 & -.310 & .864 & .006 & -.089 \\
(-3.29) & (-1.48) & (7.40) & (-1.55) & (-5.60) & (9.53) & (0.07) & (-5.30)
\end{array} \\
& \alpha D_{t}+\beta_{0} D_{t} C F_{t-1}+\beta_{1} D_{t} C F_{t}+\beta_{2} D_{t} C F_{t+1}+\gamma_{0} D_{t} A_{C C} C_{t-1}+\gamma_{1} D_{t} A C C_{t}+\gamma_{2} D_{t} A C C C_{t+1}+\beta_{3} D_{t} R_{t+1}+
\end{aligned}
$$

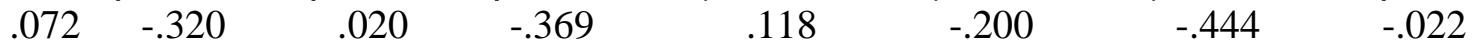

$$
\begin{aligned}
& \begin{array}{lllllll}
(3.74) & (-2.66) & (0.13) & (-2.78) & (1.59) & (-1.74) & (-4.05)
\end{array} \\
& \begin{array}{cccccccc}
\multicolumn{2}{c}{\alpha \mathrm{Z}_{\mathrm{t}}+\delta_{0} \mathrm{Z}_{\mathrm{t}} \mathrm{CF}_{\mathrm{t}-1}} & +\delta_{1} \mathrm{Z}_{\mathrm{t}} \mathrm{CF}_{\mathrm{t}}+\delta_{2} \mathrm{Z}_{\mathrm{t}} \mathrm{CF}_{\mathrm{t}+1} & +\lambda_{0} \mathrm{Z}_{\mathrm{t}} \mathrm{ACC}_{\mathrm{t}-1} & +\lambda_{1} \mathrm{Z}_{\mathrm{t}} \mathrm{ACC}_{\mathrm{t}} & +\lambda_{2} \mathrm{Z}_{\mathrm{t}} \mathrm{ACC}_{\mathrm{t}+1}+ & \delta_{3} \mathrm{Z}_{\mathrm{t}} \mathrm{R}_{\mathrm{t}+1}+\mathrm{u}_{\mathrm{t}} \\
.343 & -.478 & .352 & .900 & -.477 & .310 & .880 & .011 \\
(17.80) & (-4.92) & (2.83) & (7.65) & (-8.04) & (3.35) & (9.31) & (0.59)
\end{array}
\end{aligned}
$$

$\mathrm{R}^{2}=.092$

\begin{tabular}{|c|c|c|c|c|c|c|c|}
\hline $\begin{array}{c}\mathrm{R}_{\mathrm{t}}=\mathrm{a}+ \\
.329 \\
(22.94)\end{array}$ & $\begin{array}{l}\mathrm{b}_{0} \mathrm{CF}_{\mathrm{t}-1} \\
-.893 \\
(-10.22)\end{array}$ & $\begin{array}{c}+\mathrm{b}_{1} \mathrm{CF}_{\mathrm{t}}+ \\
1.701 \\
(14.97)\end{array}$ & $\begin{array}{l}\mathrm{b}_{2} \mathrm{CF}_{\mathrm{t}+1} \\
.018 \\
(0.20)\end{array}$ & $\begin{array}{c}+\mathrm{c}_{0} \mathrm{ACC}_{\mathrm{t}-1} \\
-.925 \\
(-13.08)\end{array}$ & $\begin{array}{l}+\mathrm{c}_{1} \mathrm{ACC}_{\mathrm{t}} \\
1.636 \\
(15.18)\end{array}$ & $\begin{array}{c}+\mathrm{c}_{2} \mathrm{ACC}_{\mathrm{t}+1} \\
.316 \\
(3.99)\end{array}$ & $\begin{array}{l}\quad+b_{3} R_{t+1}+ \\
-.082 \\
(-5.48)\end{array}$ \\
\hline $\begin{array}{l}\alpha \mathrm{D}_{\mathrm{t}}+ \\
.027 \\
(1.47)\end{array}$ & $\begin{array}{c}\beta_{0} \mathrm{D}_{\mathrm{t}} \mathrm{CF}_{\mathrm{t}-1} \\
.579 \\
(4.55)\end{array}$ & $\begin{array}{c}+\beta_{1} \mathrm{D}_{\mathrm{t}} \mathrm{CF}_{\mathrm{t}}+ \\
-1.032 \\
(-6.38)\end{array}$ & $\begin{array}{l}\beta_{2} \mathrm{D}_{t} \mathrm{CF}_{\mathrm{t}+1} \\
-.297 \\
(-2.34)\end{array}$ & $\begin{array}{c}+\gamma_{0} \mathrm{D}_{\mathrm{t}} \mathrm{ACC}_{\mathrm{t}-1}- \\
.791 \\
(9.15)\end{array}$ & $\begin{array}{c}+\gamma_{1} \mathrm{D}_{\mathrm{t}} \mathrm{ACC}_{\mathrm{t}} \\
-1.037 \\
(-8.04)\end{array}$ & $\begin{array}{c}+\gamma_{2} \mathrm{D}_{\mathrm{t}} \mathrm{ACC}_{\mathrm{t}+1}- \\
-.513 \\
(-4.84)\end{array}$ & $\begin{array}{l}+\beta_{3} D_{t} R_{t+1}+ \\
-.011 \\
(-0.54)\end{array}$ \\
\hline $\begin{array}{c}\alpha \mathrm{Z}_{\mathrm{t}}+ \\
-.393 \\
(-21.22)\end{array}$ & $\begin{array}{c}\delta_{0} \mathrm{Z}_{\mathrm{t}} \mathrm{CF}_{\mathrm{t}-1} \\
.069 \\
(0.57)\end{array}$ & $\begin{array}{c}+\delta_{1} \mathrm{Z}_{\mathrm{t}} \mathrm{CF}_{\mathrm{t}}+ \\
.542 \\
(3.66)\end{array}$ & $\begin{array}{c}\delta_{2} \mathrm{Z}_{\mathrm{t}} \mathrm{CF}_{\mathrm{t}+1} \\
1.012 \\
(7.48)\end{array}$ & $\begin{array}{c}+\lambda_{0} \mathrm{Z}_{\mathrm{t}} \mathrm{ACC}_{\mathrm{t}-1} \\
-.037 \\
(-0.47)\end{array}$ & $\begin{array}{c}+\lambda_{1} \mathrm{Z}_{\mathrm{t}} \mathrm{ACC}_{\mathrm{t}} \\
.201 \\
(1.76)\end{array}$ & $\begin{array}{c}+\lambda_{2} \mathrm{Z}_{\mathrm{t}} \mathrm{ACC}_{\mathrm{t}+1} \\
.650 \\
(5.80)\end{array}$ & $\begin{array}{l}+\delta_{3} Z_{t} R_{t+1}+u_{t} \\
-.013 \\
(-0.62)\end{array}$ \\
\hline
\end{tabular}

\section{Panel B}

Smoothing Measure is $\sigma_{\mathrm{NI}} / \sigma_{\mathrm{CFO}}$

$\mathrm{R}^{2}=.079$

\section{Notes}

See Tables 1 and 3 for variable definitions. Numbers under the variables are coefficients (and t-statistics in parentheses). $Z_{t}$ is a percentile ranking of market value of equity within each firm's (2 digit SIC code) industry- year: $Z_{t}=($ rank-1)/(number of firms in industry-year -1$)$. 
Table 10

Results of Estimation of Cross-Sectional Jones Model

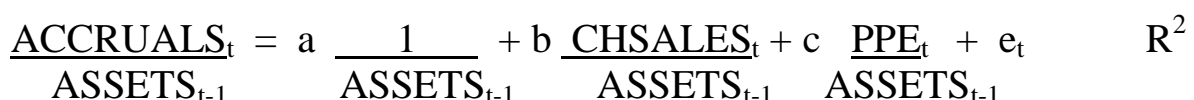

$\begin{array}{lcccc}\text { mean } & -.238 & .054 & -.079 & .232 \\ \text { std dev } & .853 & .101 & .063 & .174 \\ \text { minimum } & -6.939 & -.369 & -.565 & .005 \\ \text { median } & -.129 & .052 & -.079 & .190 \\ \text { maximum } & 3.498 & .944 & .285 & .965 \\ \mathrm{n}=423 & & & & \end{array}$




\section{Table 11}

Regressions of Returns against lagged, current, and future earnings, and interactions with smoothing measures from Jones Model, 1991 - 1999

\section{Panel A}

Smoothing Measure is $\rho\left(\Delta \mathrm{ACC}^{\mathrm{u}}, \Delta \mathrm{PDI}\right)$

$$
\begin{aligned}
& R_{t}=a+b_{0} E_{t-1}+b_{1} E_{t}+b_{2} E_{t+1}+b_{3} R_{t+1}+\alpha D_{t}+\beta_{0} D_{t} E_{t-1}+\beta_{1} D_{t} E_{t}+\beta_{2} D_{t} E_{t+1}+\beta_{3} D_{t} R_{t+1}+u_{t} \\
& \begin{array}{llllllllll}
.142 & -.637 & 1.175 & .618 & -.048 & .041 & .221 & -.307 & -.520 & -.066
\end{array} \\
& \begin{array}{lllllllll}
(14.53) & (-10.75)(13.31) & (8.74) & (-3.48) & (2.4 & (2.69) & (-2.44) & (-4.77) & (-3.04)
\end{array} \\
& \mathrm{R}^{2}=.067
\end{aligned}
$$

\section{$\underline{\text { Panel B }}$}

Smoothing Measure is $\sigma_{\mathrm{NI}} / \sigma_{\mathrm{PDI}}$

$$
\begin{aligned}
& R_{t}=a+b_{0} E_{t-1}+b_{1} E_{t}+b_{2} E_{t+1}+b_{3} R_{t+1}+\alpha D_{t}+\beta_{0} D_{t} E_{t-1}+\beta_{1} D_{t} E_{t}+\beta_{2} D_{t} E_{t+1}+\beta_{3} D_{t} R_{t+1}+u_{t}
\end{aligned}
$$

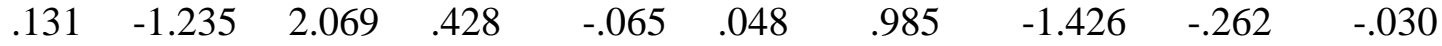

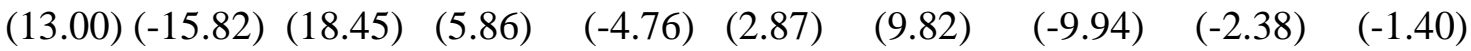

$$
\begin{aligned}
& \mathrm{R}^{2}=.071
\end{aligned}
$$

\section{$\underline{\text { Notes }}$}

See Tables 1 and 3 for variable definitions. Numbers under the variables are coefficients (and t-statistics in parentheses). 


\section{Table 12}

Regressions of Returns against lagged, current, and future cash flows and accruals, and interactions with smoothing measures from Jones Model, 1991 - 1999

\section{Panel A}

Smoothing Measure is $\rho\left(\Delta \mathrm{ACC}^{\mathrm{u}}, \Delta \mathrm{PDI}\right)$

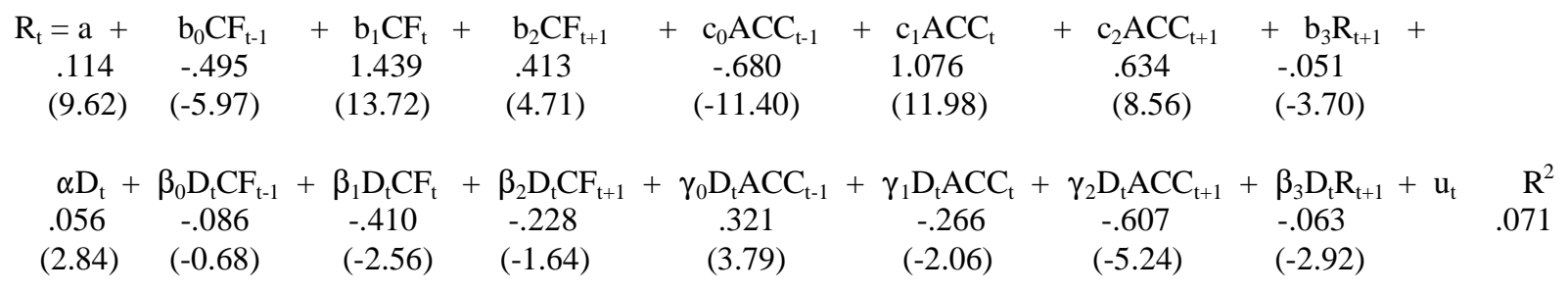

\section{$\underline{\text { Panel B }}$}

Smoothing Measure is $\sigma_{\mathrm{NI}} / \sigma_{\mathrm{PDI}}$

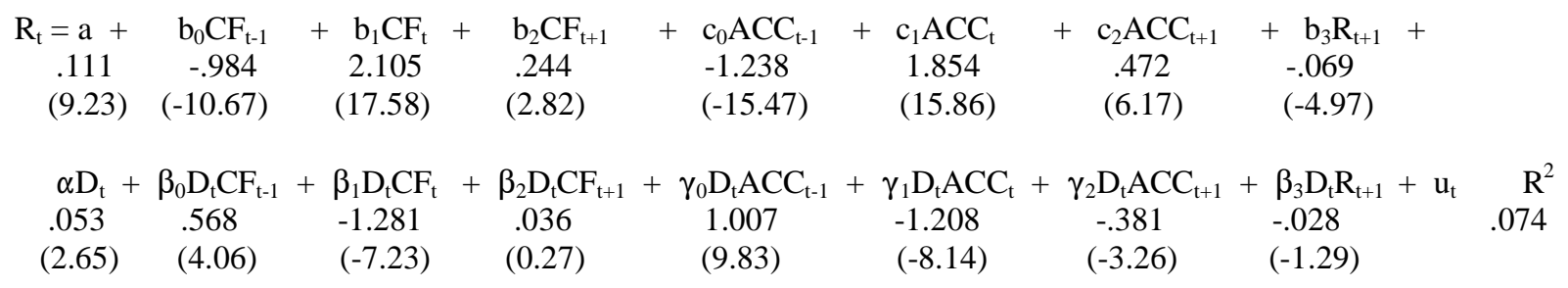

